\title{
Tissue sterol composition in Atlantic salmon (Salmo salar L.) depends on the dietary cholesterol content and on the dietary phytosterol:cholesterol ratio, but not on the dietary phytosterol content
}

\author{
Nini H. Sissener ${ }^{1 *}$, Grethe Rosenlund ${ }^{2}$, Ingunn Stubhaug ${ }^{2}$ and Nina S. Liland ${ }^{1}$ \\ ${ }^{1}$ Institute of Marine Research (IMR), PB 1870 Nordnes, 5817 Bergen, Norway \\ ${ }^{2}$ Skretting ARC, Sjøhagen 3, 4016 Stavanger, Norway \\ (Submitted 22 August 2017 - Final revision received 6 October 2017 - Accepted 29 October 2017-First published online 5 February 2018)
}

\section{Abstract}

The aim of the study was to investigate how the dietary sterol composition, including cholesterol, phytosterol:cholesterol ratio and phytosterols, affect the absorption, biliary excretion, retention, tissue storage and distribution of cholesterol and individual phytosterols in Atlantic salmon (Salmo salar L.). A feeding trial was conducted at two different temperatures ( 6 and $12^{\circ} \mathrm{C}$ ), using nine different diets with varying contents of phytosterols, cholesterol and phytosterol:cholesterol ratio. Cholesterol retention values were clearly dependent on dietary cholesterol, and showed that fish fed cholesterol levels $<1000 \mathrm{mg} / \mathrm{kg}$ feed produced considerable quantities of cholesterol de novo. Despite this production, cholesterol content increased with increasing dietary cholesterol in liver, plasma, bile, muscle, adipose tissue and whole fish at $12^{\circ} \mathrm{C}$, and in plasma, bile and whole fish at $6^{\circ} \mathrm{C}$. The tissue sterol composition generally depended on the dietary cholesterol content and on the dietary phytosterol:cholesterol ratio, but not on the dietary phytosterol content in itself. Campesterol and brassicasterol appeared to be the phytosterols with the highest intestinal absorption in Atlantic salmon. There was a high biliary excretion of campesterol, but not of brassicasterol, which accumulated in tissues and particularly in adipose tissue, with 2-fold-higher retention at $12^{\circ} \mathrm{C}$ compared with $6^{\circ} \mathrm{C}$. Campesterol had the second highest retention of the phytosterols in the fish, but with no difference between the two temperatures. Other phytosterols had very low retention. Although brassicasterol retention decreased with increasing dietary phytosterols, campesterol retention decreased with increasing dietary cholesterol, indicating differences in the uptake mechanisms for these two sterols.

\section{Key words: Atlantic salmon: Phytosterols: Cholesterol: Brassicasterol: Campesterol}

Phytosterols are the plant equivalents of cholesterol and have similar functions in plants as cholesterol has in animals, providing rigidity to cell membranes and being precursors of hormones $^{(1)}$. Phytosterols are only synthesised in plants, and thus the content of phytosterols in animals comes solely from food via intestinal absorption ${ }^{(1)}$ or, in the case of aquatic organisms, also from the water, if present there ${ }^{(2)}$. The use of vegetable oils in feeds for farmed Atlantic salmon (Salmo salar) has increased in recent years, whereas the use of fish oil has decreased. This has caused a range of changes in the salmon feeds, including decreased cholesterol levels and increased content of phytosterols. Different vegetable oils are highly variable in the amount and composition of phytosterols, with particularly high levels in maize oil and rapeseed oil ${ }^{(3)}$. Rapeseed oil is the most commonly used vegetable oil in Norwegian salmon feeds ${ }^{(4)}$. There is limited knowledge on how phytosterols may affect the fish, including effects on cholesterol absorption and homoeostasis, and how they are absorbed, excreted or deposited in the fish ${ }^{(5,6)}$. Phytosterols are well known for lowering plasma cholesterol in humans, and ingesting $2 \mathrm{~g}$ of phytosterols/d is shown to lower LDLcholesterol by approximately $10 \%{ }^{(7,8)}$.

While the phytosterols are structurally similar to cholesterol, they behave differently in the body. Compared with cholesterol, phytosterols exhibit both poorer absorption from the intestine and faster secretion from the liver; whereas cholesterol absorption in healthy humans is $>40 \%$, phytosterol absorption is $<5 \%{ }^{(9)}$. The intestinal absorption of phytosterols decreased with increasing number of side-chain $\mathrm{C}$ atoms at the 24-C position on the sterol chain moiety and with the saturation of the sterol $^{(9)}$. Phytosterols may also interfere with micellar solubilisation of cholesterol in the intestine and hence reduce its absorption $^{(10,11)}$, although this may not account for the entire effect. Furthermore, there have been suggestions that phytosterols and stanols may regulate sterol transporters, such as ATP-binding cassette transporter 1 (ABCA1) and ATP-binding

Abbreviations: ABCA1, ATP-binding cassette transporter 1; ABCG5/G8, ATP-binding cassette subfamily G members 5 and 8; NCP1L1, Niemann-Pick C1-like 1 protein.

* Corresponding author: N. H. Sissener, email nsi@hi.no 
cassette subfamily $G$ members 5 and 8 (ABCG5/G8) in the intestine. However, studies conducted with mice deficient in these transporters have shown that this is not the case, and the discussion regarding the exact molecular mechanism behind the reduction in intestinal cholesterol absorption by phytosterols continues ${ }^{(12)}$.

The effects of individual phytosterols have not been well studied, as they are mostly provided together in clinical trials ${ }^{(13)}$. However, it is clear that different phytosterols are absorbed to different extents; in rats there was $13 \%$ absorption of campesterol, approximately $4 \%$ absorption of $\beta$-sitosterol and stigmasterol and only $1-2 \%$ of $\beta$-sitostanol and campestanol ${ }^{(14)}$. Phytosterol accumulation was also variable between different tissues, with the highest amounts retained in the adrenal glands, ovaries and intestinal epithelia ${ }^{(14)}$. This corresponds well with a higher apparent digestibility and accumulation of campesterol than $\beta$-sitosterol in Altantic salmon ${ }^{(5)}$. In macrophage foam cells, stigmasterol increased the expression of ABCA1 and ABCG1, whereas campesterol and $\beta$-sitosterol had no effect $^{(15)}$, demonstrating distinct biological activities of the individual phytosterols

As most research on phytosterols has been conducted in mammals with a constant body temperature, it is unclear how temperature may affect factors such as phytosterol absorption, interference with cholesterol absorption and tissue retention/ distribution. The rearing temperature of Atlantic salmon greatly affects both the general rate of metabolism and lipid digestion and transport in particular ${ }^{(16,17)}$. Furthermore, cholesterol uptake was shown to be temperature dependent in an in vitro human intestine model ${ }^{(18)}$. Cholesterol has an important role in thermal adaptation in ectotherm animals, as incorporation of cholesterol in biological membranes affects membrane order and fluidity, stabilising membranes at high temperature ${ }^{(19)}$, which may lead to differences in tissue sterol incorporation at different temperatures.

The aim of the present work was to investigate how the dietary sterol composition, including cholesterol, phytosterol: cholesterol ratio and phytosterols, affects the absorption, biliary excretion, retention and tissue storage and distribution of cholesterol and individual phytosterols in Atlantic salmon reared at two different temperatures.

\section{Methods}

\section{Feeds and feeding trial}

In total, nine fish diets were made, all containing the same basal ingredients, and only differing in the addition of cholesterol (Cholesterol SF; Dishman Netherlands B.V.) or a phytosterol mix (CardioAid Plant Sterols; ADM). This gave a range of different cholesterol and phytosterol feed concentrations, as well as varying phytosterol:cholesterol ratios (Table 1). The diets were named according to their added level of phytosterols and cholesterol - for example diet 1000/0 has $1000 \mathrm{mg} / \mathrm{kg}$ added phytosterols and no added cholesterol (actual sterol content was higher owing to the contribution from the basal feed ingredients). In addition to the proximate composition and analysed sterol content given in Table 1, further details on diet formulation and composition are published elsewhere ${ }^{(20)}$.
The feeding trial was carried out at Skretting ARC Research Station Lerang (Stavanger, Norway), and was conducted according to the guidelines of the Norwegian State Commission for Laboratory Animals. After 2 weeks of acclimatisation, Atlantic salmon (Salmobreed from Erfjord Stamfisk) with an initial body weight of $250 \mathrm{~g}$ (SD 29) was reared in 1-m circular tanks supplied with flow through seawater at 12 or $6^{\circ} \mathrm{C}$ and exposed to 24-h light. Each tank was stocked with thirty-two fish, and the trial lasted 16 weeks at $12^{\circ} \mathrm{C}$ and 23 weeks at $6^{\circ} \mathrm{C}$, respectively, to allow the fish to reach similar final body weights of approximately $900 \mathrm{~g}$. Each of the nine experimental diets were fed to triplicate tanks at $12^{\circ} \mathrm{C}$ and to duplicate tanks at $6^{\circ} \mathrm{C}$ using automatic feeders (Hølland Teknologi AS). Feed was given in slight excess during three meals per day (07.30-09.30; 12.00-14.00; 20.00-22.00 hours) and surplus feed was collected daily to determine feed intake. Standard husbandry routines at the station were followed.

\section{Sampling}

At the final samplings at both temperatures, feeding was stopped $24 \mathrm{~h}$ before sampling for each tank. The fish were anaesthetised with tricaine methanesulfonate (Tricaine Pharmaq) at a concentration of $40 \mathrm{mg} / \mathrm{l}$ and killed by a blow to the head. Homogenised pooled samples were made from fillet (Norwegian quality cut) of six fish per tank and whole fish of another six fish per tank. Blood was collected using vacutainers from six fish per tank, and centrifuged at $3000 \mathrm{~g}$ for $7 \mathrm{~min}$ to obtain the plasma fraction, which was frozen on dry ice and stored at $-80^{\circ} \mathrm{C}$. Mid-intestinal samples for RNA extraction were flash-frozen in liquid $\mathrm{N}_{2}$ (individual samples, six fish per tank), whereas mid-intestine samples for sterol analyses were frozen on dry ice (pooled samples, six fish per tank) and all samples were stored at $-80^{\circ} \mathrm{C}$. Before the intestinal samples were frozen, they were opened longitudinally and flushed with PBS to remove intestinal content. Pooled samples of liver and adipose tissue were also collected and frozen on dry ice (pooled samples, six fish per tank), whereas bile was collected from the gall bladder with a syringe and two aliquots of pooled samples were made (six fish per tank).

\section{Analyses of sterol content}

Analyses of phytosterol and cholesterol content in feed, midintestine, liver, bile, fillet, visceral adipose tissue and whole fish samples were performed as described by Laakso ${ }^{(21)}$. The internal standard, 5- $\beta$-cholestan-3- $\alpha$-ol, dissolved in isopropanol to $0.6 \mathrm{mg} / \mathrm{ml}$, was added to the samples before saponification. The samples were directly saponified without prior lipid extraction in $2.5 \mathrm{ml}$ of $2 \mathrm{M} \mathrm{KOH}$ solution in an ultrasonic bath for an hour at $65-75^{\circ} \mathrm{C}$. After samples were chilled to room temperature, $2 \mathrm{ml}$ of water and $3 \mathrm{ml}$ of hexane were added and samples centrifuged for $1 \mathrm{~min}$ at $3000 \mathrm{rpm}$. Then, the hexane phase was collected and the extraction process repeated with $3 \mathrm{ml}$ of hexane. The extract was dried on a heat block (maximum $70^{\circ} \mathrm{C}$ ) with $\mathrm{N}_{2}$ flow and then derivatised to trimetylsilyl ether of sterols by adding $100 \mu \mathrm{l}$ of pyridine and $200 \mu$ of silylation reagent (bis[trimethylsilyl]-trifluoroacetamide 
with $1 \%$ trimethylchlorosilane) and warmed on a heat block at $70^{\circ} \mathrm{C}$ for $15 \mathrm{~min}$. The samples were diluted $20 \times$ in hexane before analysis on a GC. The following instrumentation was used: Thermoquest trace GC 2000 with an autosampler AS2000 (Thermo Finnigan Quest), on-column injector, flame ionisation detector and the column Equity-5 WCOT $30 \mathrm{~m} \times 0.25 \mathrm{~mm}$ i.d. (Supelco). Helium was used as a carrier gas at $0.9 \mathrm{ml} / \mathrm{min}$; hydrogen and air were used as detector gases at 35 and $350 \mathrm{ml} /$ min, respectively. Temperature started at $100^{\circ} \mathrm{C}$, increased by $50^{\circ} \mathrm{C} / \mathrm{min}$ to $300^{\circ} \mathrm{C}$ and was kept for $12 \mathrm{~min}$. The peaks were identified with the software Chromeleon ${ }^{\circledR}$ version 6.8. Phytosterol-enriched margarine of the brand vita pro-aktiv (Mills DA) was used as control material.

Plasma cholesterol was analysed using a clinical bioanalyzer (Maxmat PL analyzer) according to standardised procedures, reagents and controls. Osmolarity was analysed in bile by measuring the freezing point with Fiske One Ten Osmometer (Fiske Associated).

\section{Gene expression}

Total RNA was extracted from intestinal tissue using the EZ1 RNA universal tissue kit (Qiagen) according to the manufacturer's instructions. Quantity and quality of the RNA were assessed by spectrophotometry and the Agilent 2100 Bioanalyzer (Agilent Technologies) as described previously ${ }^{(22)}$. RNA integrity number (RIN) was tested for a subset of samples that all had RIN values $>9$. A two-step PCR was conducted on the target genes acetyl-COA acetyltransferase 2 (ACAT2), Niemann-Pick C1-like 1 protein (NCP1L1), ABCG5 and ABCA1 and reference genes $\beta$-actin, elongations factor $1 \alpha$ (EF1 $\alpha)$ and acidic ribosomal phosphoprotein $(A R P)$. RT was performed on a GeneAmp PCR 9700 (Applied Biosystems) using the TaqMan ${ }^{\circledR}$ reverse transcriptase kit with oligo (dT) primers (Applied Biosystems). Samples were run in duplicate ( $500 \mathrm{ng}, \pm 5 \%$ ), in addition to a six-point dilution curve in triplicate (1000 to $31 \cdot 25 \mathrm{ng}$ ), non-template and non-amplification controls. Real-time PCR amplification and analysis were performed on a LightCycler 480 Real-time PCR system (Roche Applied Science) with SYBR ${ }^{\circledR}$ Green I Mastermix (Roche Applied Science). Pipetting of plates was done using a Biomek ${ }^{\circledR} 3000$ Laboratory automation workstation (Beckman Coulter, Fullerton). Thermal cycling was done for forty-five cycles of $10 \mathrm{~s}$ at each of 95,60 and $72^{\circ} \mathrm{C}$, followed by melting curve analysis to confirm that only one product was present. Cycle threshold $\left(C_{t}\right)$ values were calculated using the second maximum derivative method in the Lightcycler ${ }^{\circledR}$ software. Amplification efficiency was determined using the dilution curves with the formula $E=10^{(-1 / \text { slope })}$, with the slope of the linear curve of $C_{t}$-values plotted against the log-dilution ${ }^{(23)}$. Inter-plate calibration was done according to TATAA (http://www. eppendorf.com/content/1/1/img/20071004_London.pdf). The stability of the expression of each reference gene was calculated from the $C_{t}$ values using the program geNorm ${ }^{(24)}$ according to the geNorm manual.

\section{Calculations, data treatment and statistical analyses}

The retention (which in the case of cholesterol also will include de novo production and hence might give 'retention' values $>100 \%$ if there is a net production of cholesterol in the fish) of individual sterols was calculated according to this formula: nutrient retention $=(($ final biomass $\times$ final nutrient content) $-($ initial biomass $\times$ initial nutrient content) $) \times 100 /$ (total feed intake $\times$ nutrient content in feed). Linear regression analyses based on feed content of phytosterols, cholesterol and the phytosterol:cholesterol ratio were conducted in GraphPad Prism 6.0 (Graphpad Software Inc.). One-way ANOVA followed by Tukey's post hoc test of sterol ratios was performed in Statistica (version 13.1, Statsoft). Tissue sterol composition at the two temperatures were compared by two-sided $t$ test. Statistical analyses of the data from quantitative PCR were performed using the free software environment $\mathrm{R}^{(25)}$. Differences between the dietary groups were detected by nested one-way ANOVA (random effect factor: tank) and Tukey's post hoc test using the packages nlme $e^{(26)}$ and multcomp ${ }^{(27)}$, or Kruskal-Wallis when the assumptions of ANOVA were not met. $P$-values $<0.05$ are regarded as statistically significant.

\section{Results}

\section{Sterol composition in diets}

The proximate composition and sterol composition of the diets have already been published ${ }^{(20)}$, but were also included here (Table 1) for a better understanding of the presented results. In the nine experimental diets, the phytosterol concentrations ranged from 1353 to $3147 \mathrm{mg} / \mathrm{kg}$ feed, cholesterol from 867 to $3153 \mathrm{mg} / \mathrm{kg}$ feed and phytosterol:cholesterol ratio from 0.7 to $3 \cdot 2$.

\section{Tissue sterol composition}

Sterol concentrations and composition varied between tissues (Table 2). Cholesterol levels were highest in the liver and midintestine, followed by adipose tissue, whole body, muscle and finally bile. While phytosterols constituted $2 \cdot 0-6 \cdot 6 \%$ of total sterols in other tissues, they constituted $36.7-46.5 \%$ in the bile (mean values at the two different temperatures). Mid-intestine and adipose tissue had a slightly higher proportion phytosterols of total sterols (5.0-6.6\%) compared with liver and muscle (2.0-3.1\%).

There were some temperature effects on tissue sterol composition (Table 2). In the mid-intestine, the total amount of both cholesterol and phytosterols was similar, but there were significant differences in the proportions of the individual phytosterols, with a higher proportion of brassicasterol $(P=0.0003)$ and sitostanol $(P<0.0001)$ at $12^{\circ} \mathrm{C}$, but lower campesterol $(P=0 \cdot 03)$. In the liver, both cholesterol and phytosterol concentrations were lower at $12^{\circ} \mathrm{C}$ (both $P<0 \cdot 0001$ ). The phytosterol distribution also differed with temperature, with a higher proportion brassicasterol at $12^{\circ} \mathrm{C}(P<0.0001)$, whereas the proportions of campestanol $(P=0.007)$, stigmasterol $(P=0.01)$ and $\beta$-sitosterol $(P=0.03)$ were lower. In the bile, there were significantly less phytosterols at $12^{\circ} \mathrm{C}(P<0.0001)$, but the proportion of brassicasterol $(P<0 \cdot 0001)$ and sitostanol was higher $(P=0.0005)$. In adipose tissue, the cholesterol concentration was significantly higher at $12^{\circ} \mathrm{C}(P<0 \cdot 0001)$. Furthermore, phytosterols were similar; there was a higher proportion of brassicasterol and stigmasterol (both $P<0 \cdot 0001$ ), 
Table 1. Analysed feed composition, including proximate composition and sterols (also previously published ${ }^{(20)}$ )

\begin{tabular}{|c|c|c|c|c|c|c|c|c|c|}
\hline & $0 / 0$ & 0/1000 & $500 / 0$ & $1000 / 0$ & $1000 / 1000$ & $1000 / 3000$ & $1500 / 0$ & $2000 / 0$ & $2000 / 2000$ \\
\hline \multicolumn{10}{|l|}{ Composition (\%) } \\
\hline Moisture & $6 \cdot 8$ & $6 \cdot 7$ & 6.6 & $6 \cdot 7$ & $6 \cdot 8$ & $6 \cdot 9$ & 6.6 & 6.4 & 6.6 \\
\hline Protein & 44.9 & 44.3 & 44.6 & 44.8 & 44.0 & 44.3 & 44.8 & 44.8 & 44.4 \\
\hline Fat & $29 \cdot 6$ & 29.5 & $29 \cdot 0$ & $29 \cdot 6$ & $29 \cdot 4$ & $29 \cdot 1$ & $29 \cdot 6$ & $28 \cdot 4$ & $28 \cdot 7$ \\
\hline Ash & $5 \cdot 2$ & $5 \cdot 2$ & $5 \cdot 2$ & $5 \cdot 2$ & $5 \cdot 1$ & $5 \cdot 2$ & $5 \cdot 2$ & $5 \cdot 3$ & $5 \cdot 2$ \\
\hline \multicolumn{10}{|l|}{ Sterols (mg/kg feed) } \\
\hline Cholesterol & 877 & 1563 & 867 & 889 & 1567 & 3153 & 927 & 896 & 2398 \\
\hline Brassicasterol & 87 & 86 & 76 & 89 & 94 & 94 & 102 & 106 & 120 \\
\hline Campesterol & 318 & 319 & 419 & 550 & 533 & 532 & 625 & 738 & 812 \\
\hline Campestanol & 15 & 14 & 21 & 20 & 16 & 21 & 17 & 29 & 24 \\
\hline Stigmasterol & 28 & 25 & 99 & 174 & 163 & 165 & 250 & 340 & 382 \\
\hline$\beta$-Sitosterol & 743 & 722 & 847 & 1096 & 1090 & 1039 & 1248 & 1412 & 1550 \\
\hline Sitostanol & 83 & 87 & 79 & 114 & 120 & 94 & 126 & 127 & 129 \\
\hline Stigmasta-5,24-dienol & 15 & 10 & 11 & 28 & 12 & 10 & 14 & 13 & 15 \\
\hline Stigmast-7-enol & 104 & 90 & 95 & 110 & 109 & 102 & 112 & 114 & 121 \\
\hline Sum phytosterols & 1399 & 1353 & 1610 & 2181 & 2136 & 2056 & 2491 & 2876 & 3147 \\
\hline Phytosterol:cholesterol ratio & 1.59 & 0.87 & 1.86 & 2.45 & 1.36 & 0.65 & $2 \cdot 69$ & $3 \cdot 21$ & 1.31 \\
\hline
\end{tabular}

Table 2. Tissue sterol composition in Atlantic salmon*

(Mean values and standard deviations)

\begin{tabular}{|c|c|c|c|c|c|c|c|c|c|c|c|c|}
\hline & \multicolumn{2}{|c|}{ Mid-intestine } & \multicolumn{2}{|c|}{ Liver } & \multicolumn{2}{|c|}{ Bile } & \multicolumn{2}{|c|}{ Muscle } & \multicolumn{2}{|c|}{ Adipose tissue } & \multicolumn{2}{|c|}{ Whole fish } \\
\hline & Mean & SD & Mean & SD & Mean & SD & Mean & SD & Mean & SD & Mean & SD \\
\hline \multicolumn{13}{|c|}{ Atlantic salmon reared at $12^{\circ} \mathrm{C}$} \\
\hline Chol (mg/kg) & 3045 & 161 & 3048 & 130 & 197 & 20 & 698 & 36 & 1609 & 119 & 1217 & 63 \\
\hline Sum phyto (mg/kg) & 163 & 34 & 63.5 & $15 \cdot 8$ & 115 & 26 & $22 \cdot 3$ & $5 \cdot 8$ & $84 \cdot 4$ & 8.5 & $46 \cdot 5$ & $12 \cdot 2$ \\
\hline$\%$ Phyto of total sterols & $5 \cdot 1$ & 1.0 & $2 \cdot 0$ & 0.5 & $36 \cdot 7$ & $7 \cdot 0$ & $3 \cdot 1$ & 0.8 & $5 \cdot 0$ & 0.6 & $3 \cdot 7$ & 1.0 \\
\hline \multicolumn{13}{|c|}{ Individual phytosterols in $\%$ of total phytosterols, $12^{\circ} \mathrm{C}$} \\
\hline Brassicasterol (\%) & $8 \cdot 0$ & $2 \cdot 1$ & $13 \cdot 1$ & 4.4 & 1.8 & 0.5 & $30 \cdot 6$ & $7 \cdot 3$ & $56 \cdot 6$ & $6 \cdot 8$ & $29 \cdot 3$ & 3.9 \\
\hline Campesterol (\%) & $56 \cdot 9$ & 4.9 & $57 \cdot 0$ & $7 \cdot 3$ & $68 \cdot 1$ & 1.8 & 38.6 & $6 \cdot 3$ & $21 \cdot 6$ & $4 \cdot 6$ & $38 \cdot 6$ & $6 \cdot 8$ \\
\hline Campestanol (\%) & 0.8 & $0 \cdot 2$ & 0.8 & 0.7 & ND & - & $3 \cdot 1$ & $1 \cdot 8$ & 0.6 & 0.3 & 0.7 & 0.7 \\
\hline Stigmasterol (\%) & 1.9 & 0.9 & $2 \cdot 2$ & $1 \cdot 3$ & 0.4 & $0 \cdot 1$ & $5 \cdot 1$ & 3.0 & 5.9 & $2 \cdot 2$ & 2.7 & 0.9 \\
\hline$\beta$-Sitosterol (\%) & $26 \cdot 7$ & $4 \cdot 7$ & $21 \cdot 7$ & $7 \cdot 2$ & 21.9 & $1 \cdot 2$ & $12 \cdot 6$ & $6 \cdot 6$ & $9 \cdot 3$ & $2 \cdot 2$ & $25 \cdot 6$ & $8 \cdot 8$ \\
\hline Sitostanol (\%) & $3 \cdot 7$ & 0.6 & 4.9 & $1 \cdot 2$ & $5 \cdot 6$ & 0.7 & $5 \cdot 3$ & $1 \cdot 4$ & $5 \cdot 8$ & $1 \cdot 2$ & 3.0 & 0.8 \\
\hline \multicolumn{13}{|c|}{ Atlantic salmon reared at $6^{\circ} \mathrm{C}$} \\
\hline Chol (mg/kg) & 3025 & 278 & 4319 & 762 & 186 & 22 & 742 & 33 & 1267 & 133 & 1255 & 67 \\
\hline Sum phyto (mg/kg) & $182 \cdot 0$ & 33 & $107 \cdot 6$ & $26 \cdot 7$ & 163 & 37 & $20 \cdot 6$ & 3.9 & $90 \cdot 4$ & 38.4 & $43 \cdot 1$ & $6 \cdot 2$ \\
\hline$\%$ Phyto of total sterols & $5 \cdot 7$ & 1.2 & 2.5 & 0.6 & $46 \cdot 5$ & $7 \cdot 7$ & $2 \cdot 7$ & 0.5 & $6 \cdot 6$ & $2 \cdot 3$ & $3 \cdot 3$ & 0.5 \\
\hline \multicolumn{13}{|c|}{ Individual phytosterols in $\%$ of total phytosterols, $6^{\circ} \mathrm{C}$} \\
\hline Brassicasterol (\%) & $5 \cdot 9$ & 1.2 & $8 \cdot 5$ & 1.7 & $1 \cdot 3$ & 0.4 & $17 \cdot 9$ & 3.6 & $36 \cdot 4$ & $9 \cdot 9$ & 19.5 & 3.0 \\
\hline Campesterol (\%) & 59.8 & $3 \cdot 1$ & $53 \cdot 0$ & $7 \cdot 6$ & $69 \cdot 2$ & 3.9 & $45 \cdot 7$ & $5 \cdot 7$ & $24 \cdot 3$ & $6 \cdot 3$ & 44.9 & 4.6 \\
\hline Campestanol (\%) & 0.7 & 0.2 & 1.4 & 0.5 & 0.2 & 0.2 & $2 \cdot 6$ & 1.6 & 1.4 & 0.6 & $1 \cdot 1$ & 0.4 \\
\hline Stigmasterol (\%) & 1.9 & 0.8 & $3 \cdot 1$ & 0.9 & 0.5 & 0.3 & $4 \cdot 2$ & $1 \cdot 3$ & $2 \cdot 2$ & 0.6 & $3 \cdot 3$ & 0.9 \\
\hline$\beta$-Sitosterol (\%) & $27 \cdot 7$ & $2 \cdot 2$ & $26 \cdot 4$ & $6 \cdot 4$ & $22 \cdot 2$ & 2.9 & 23.5 & 4.4 & $25 \cdot 2$ & $10 \cdot 8$ & $25 \cdot 9$ & 3.7 \\
\hline Sitostanol (\%) & 2.4 & 1.0 & $4 \cdot 7$ & $2 \cdot 2$ & 4.5 & 0.6 & $5 \cdot 3$ & 1.6 & $7 \cdot 1$ & $1 \cdot 3$ & $5 \cdot 1$ & 0.9 \\
\hline
\end{tabular}

Phyto, phytosterol; chol, cholesterol.

* Cholesterol and total phytosterol content are given as $\mathrm{mg} / \mathrm{kg}$, phytosterols in percentage of total sterols and individual phytosterols in percentage of total phytosterols. All diet groups are combined, stigmasta-dienol, stigmast-enol and day-7-avenasterol were not included in the table as individual phytosterols, as they were not detected in some tissues and when detected numbers were low and the standards deviations were generally larger than the mean values, but these are included in the 'sum phytosterols'. Statistical differences between the two temperatures are given in the main text.

whereas campestanol and $\beta$-sitosterol were lower (both $P<0 \cdot 0001)$. In muscle, cholesterol concentration was significantly lower at $12^{\circ} \mathrm{C}(P=0.0002)$. Total phytosterols were once again similar, but with a higher proportion of brassicasterol $(P<0.0001)$ and lower campesterol $(P=0.0004)$ and $\beta$-sitosterol $(P<0.0001)$ at $12^{\circ} \mathrm{C}$. In whole fish, only the distribution of individual phytosterols differed between the two temperatures, with higher brassicasterol $(P<0.0001)$ and lower campesterol $(P=0.0001)$, campestanol $(P=0.03)$, stigmasterol $(P=0.02)$ and sitostanol $(P<0.0001)$ at $12^{\circ} \mathrm{C}$.
Plasma cholesterol correlated positively with dietary cholesterol both at 6 and $12^{\circ} \mathrm{C}$, both 24 and $48 \mathrm{~h}$ after the last feeding (Fig. 1). There were also significant negative correlations to the dietary phytosterol:cholesterol ratio (data not shown). At $6^{\circ} \mathrm{C}$, this correlation was equally strong as for dietary cholesterol after $24 \mathrm{~h}$, but stronger after $48 \mathrm{~h}\left(R^{2} 0 \cdot 48\right)$, whereas the correlation to the ratio was poorer at $12^{\circ} \mathrm{C}\left(R^{2} 0.15\right.$ and 0.24 at the two time points after feeding) (data not shown). Generally, tissue cholesterol correlated to dietary cholesterol in most tissues (except mid-intestine) at $12^{\circ} \mathrm{C}$, but only in bile and 
(A)

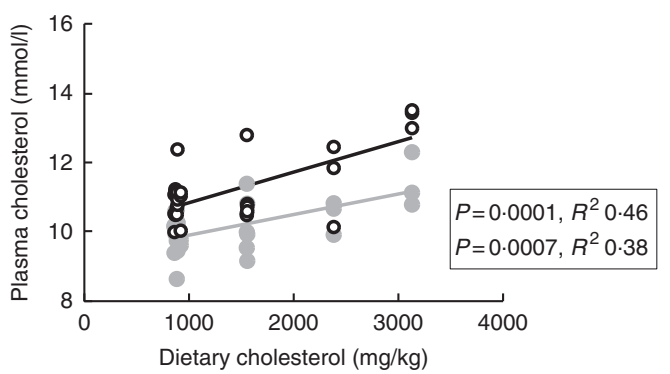

(B)

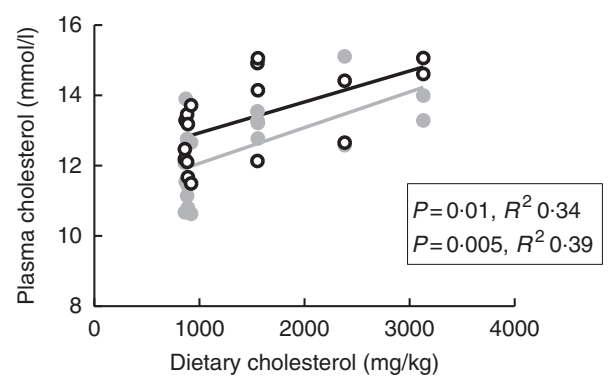

Fig. 1. Plasma cholesterol 24 (-O) and $48 \mathrm{~h}(-\odot)$ after feeding in Atlantic salmon fed different levels of dietary cholesterol at $12^{\circ} \mathrm{C}(\mathrm{A})$ and $6^{\circ} \mathrm{C}(\mathrm{B})$, respectively. Each data point represents one fish tank, based on the analysis of a pooled sample consisting of six individual fish.

(A)

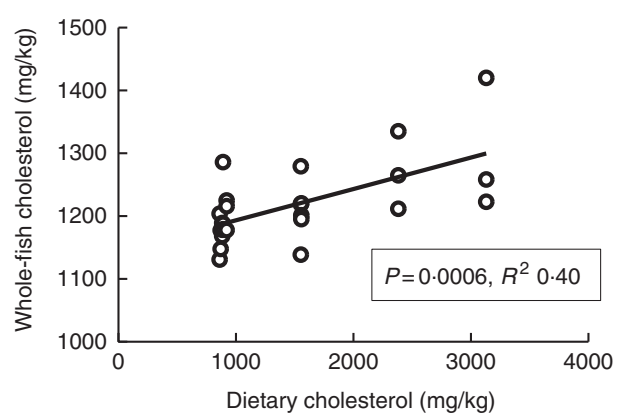

(C)

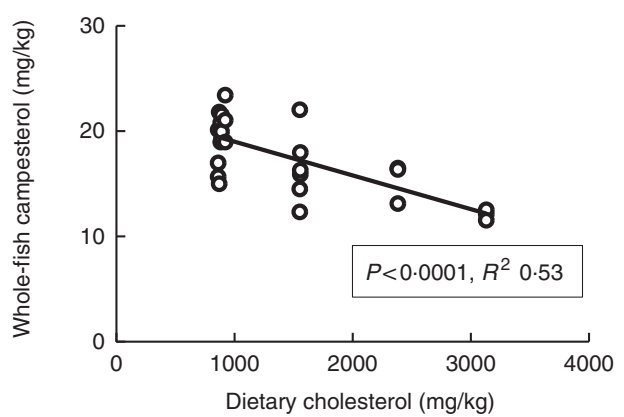

(B)

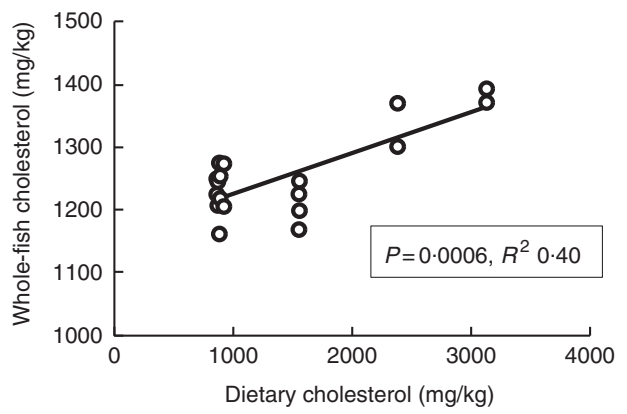

(D)

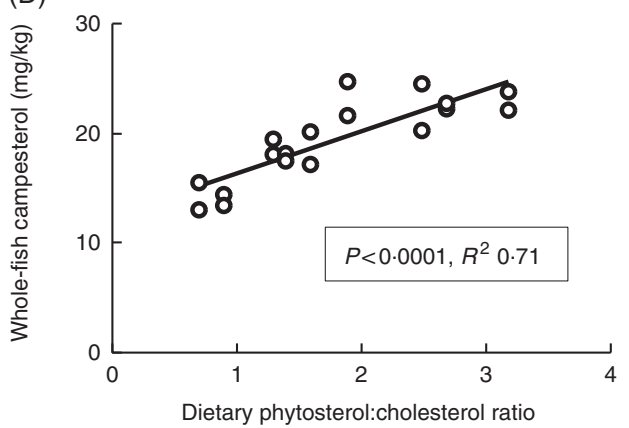

Fig. 2. Whole-fish cholesterol (A, B) and campesterol (C, D) levels in tissues of Atlantic salmon, related to dietary sterol content at 12 and $6^{\circ} \mathrm{C}$, respectively. For each tissue sterol and temperature, correlations to dietary cholesterol, dietary phytosterol and dietary phytosterol:cholesterol ratio were tested, and the strongest correlation is shown in the figure (a full overview of the statistical results for all correlations are found in supplementary data). Each data point represents one fish tank, based on the analysis of one pooled sample consisting of six individual fish.

whole fish at $6^{\circ} \mathrm{C}$. The statistical results for all significant regressions are given in the online Supplementary data, whereas cholesterol and campesterol in whole fish are shown in Fig. 2. In some instances, there were also negative correlations to the dietary phytosterol:cholesterol ratio, but these were never as strong as the correlations to dietary cholesterol by itself. Tissue campesterol content generally correlated negatively to dietary cholesterol and positively to dietary phytosterol:cholesterol ratio (with mid-intestine at $6^{\circ} \mathrm{C}$ as the only exception), and it varied whether the strongest correlation was to dietary cholesterol or to the ratio (Fig. 2, online Supplementary Table S1). As campesterol was the main phytosterol in most tissues, significant regressions for campesterol were generally accompanied by significant regressions for total phytosterols and for phytosterols as percentage of total sterols. Neither tissue cholesterol, campesterol nor total phytosterols correlated to dietary phytosterols by themselves in any tissue at either temperature. In the intestine, also brassicasterol, campestanol and sitostanol correlated positively to dietary phytosterol:cholesterol ratio at $12^{\circ} \mathrm{C}$, whereas sitostanol correlated both to dietary cholesterol and to the ratio at the same temperature. The content of brassicasterol, stigmasterol, $\beta$-sitosterol and sitostanol in bile was also affected by dietary cholesterol and/or phytosterol:cholesterol ratio. Sitostanol content was affected by dietary cholesterol and/or phytosterol: cholesterol ratio both in muscle, adipose tissue and whole fish at $12^{\circ} \mathrm{C}$, but not at $6^{\circ} \mathrm{C}$. Campestanol and stigmasterol, which were both present in tissues in low concentrations, were the only sterols in which tissue concentrations correlated with dietary phytosterols in several tissues, but only at $6^{\circ} \mathrm{C}$. 


\section{Sterol retention}

Whole-body retention of cholesterol was clearly dependent on dietary cholesterol (Fig. 3), with decreasing retention as dietary levels increased. The diet with the lowest cholesterol content had retention values of $162 \%$ (sD 9) and $176 \%$ (SD 2) at 12 and $6^{\circ} \mathrm{C}$, respectively. Furthermore, all diets containing $<1000 \mathrm{mg} / \mathrm{kg}$ cholesterol (the five diets without added cholesterol) had cholesterol retention values $>157 \%$ at both temperatures. The diets with added cholesterol on the other hand (>1500 mg cholesterol $/ \mathrm{kg}$ feed) consistently had retention values below $100 \%$ at both temperatures, with the highest cholesterol diet giving retention values of $51 \%(\mathrm{SD} 6)$ and $55 \%$ (sD 1) at 12 and $6^{\circ} \mathrm{C}$, respectively. The retention of campesterol correlated negatively with both dietary cholesterol and dietary phytosterol content, but dietary cholesterol could explain more

(A)

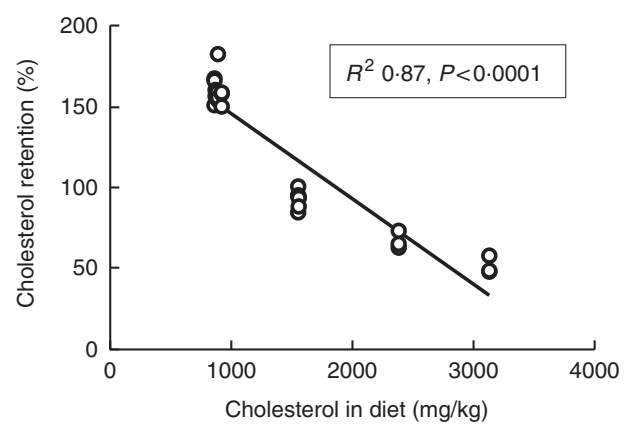

(C)

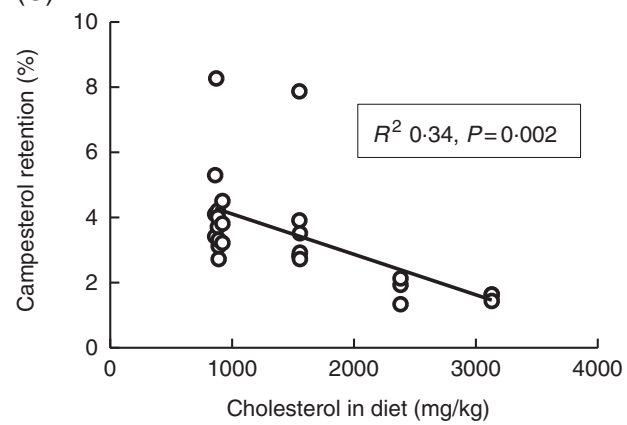

(E)

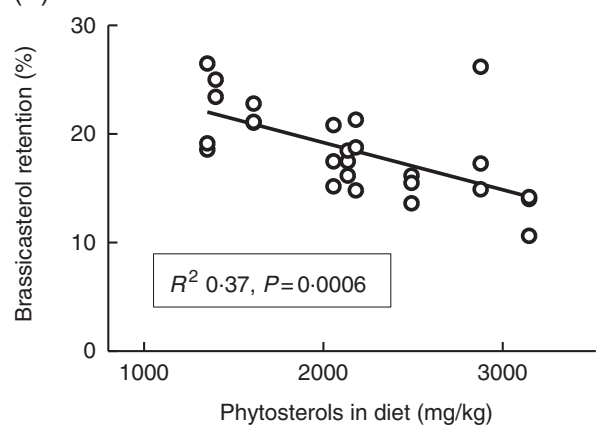

of the variation in retention values at both temperatures, with $R^{2}$ values of 0.34 and $0.54 v .0 .30$ and 0.28 for dietary phytosterols at the two temperatures. Retention of brassicasterol correlated negatively with dietary phytosterol content at both temperatures (Fig. 3), but not with dietary cholesterol. For $\beta$-sitosterol and sitostanol, effects were more inconsistent, possibly related to the low retention values and hence larger variation ( $\beta$-sitosterol mean $1.5 \%$, SD 1.9 at $12^{\circ} \mathrm{C}$, sitostanol mean $1.5 \%$, SD 0.7 at $\left.12^{\circ} \mathrm{C}\right)$. Sitosterol retention correlated negatively to dietary phytosterol at $12\left(R^{2} 0 \cdot 24, P=0 \cdot 01\right)$, but not at $6^{\circ} \mathrm{C}$ (data not shown). Sitostanol retention correlated negatively to dietary cholesterol at $12^{\circ} \mathrm{C}\left(R^{2} 0.43, P=0.0003\right)$, but to dietary phytosterols at $6{ }^{\circ} \mathrm{C}\left(R^{2} 0 \cdot 45, P=0.002\right.$, data not shown). Retention levels were highly variable between the individual phytosterols, with brassicasterol $>$ campesterol $>$ sitostanol $>\beta$-sitosterol (Table 3). Retention of the other

(B)

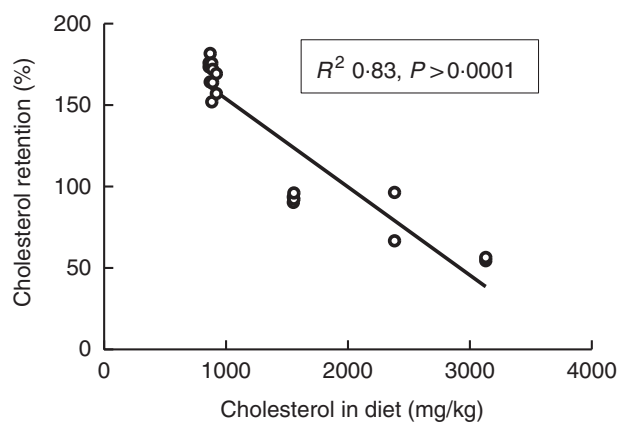

(D)

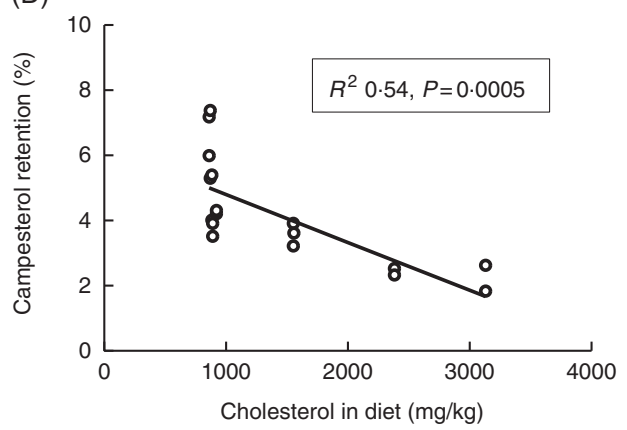

(F)

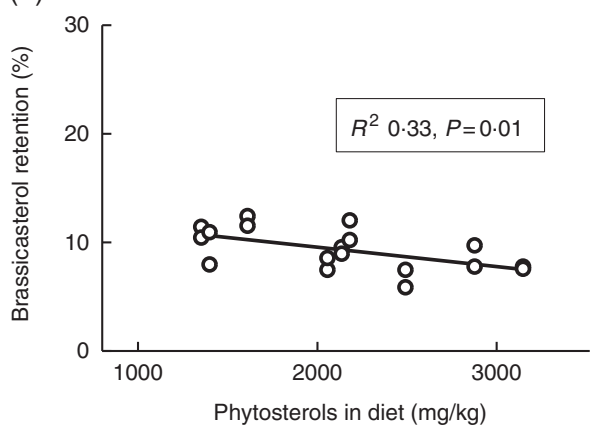

Fig. 3. Retention of cholesterol $(A, B)$, campesterol $(C, D)$ and brassicasterol $(E, F)$ in the whole body of Atlantic salmon during the whole feeding trial, related to dietary sterol content at 12 and $6^{\circ} \mathrm{C}$, respectively. For each tissue sterol and temperature, correlations to dietary cholesterol, dietary phytosterol and dietary phytosterol: cholesterol ratio were tested, and the strongest correlation is shown in the figure. Retention was calculated as follows: nutrient retention $=(($ final biomass $\times$ final nutrient content) - (initial biomass $\times$ initial nutrient content)) $\times 100 /$ (total feed intake $\times$ nutrient content in feed). Each data point represents one fish tank, based on the analysis of a pooled sample consisting of six individual fish. 
Table 3. Mean sterol retention (\%) across all diet groups at 12 and $6^{\circ} \mathrm{C}$, respectively ${ }^{*}$ (Mean values and standard deviations)

\begin{tabular}{|c|c|c|c|c|c|c|c|c|c|c|c|c|}
\hline & \multicolumn{2}{|c|}{ Cholesterol } & \multicolumn{2}{|c|}{ Brassicasterol } & \multicolumn{2}{|c|}{ Campesterol } & \multicolumn{2}{|c|}{$\beta$-Sitosterol } & \multicolumn{2}{|c|}{ Sitostanol } & \multicolumn{2}{|c|}{ Sum phyto } \\
\hline & Mean & $\mathrm{SD}$ & Mean & $\mathrm{SD}$ & Mean & SD & Mean & SD & Mean & SD & Mean & SD \\
\hline $12^{\circ} \mathrm{C}$ & 121 & 45 & 18.5 & $4 \cdot 1$ & 3.5 & $1 \cdot 7$ & 1.5 & 1.9 & 1.5 & 0.7 & $2 \cdot 6$ & 1.6 \\
\hline $6^{\circ} \mathrm{C}$ & 130 & 47 & 9.3 & 1.9 & $4 \cdot 1$ & 1.6 & 1.1 & 0.6 & 2.9 & 1.0 & $2 \cdot 3$ & 0.8 \\
\hline
\end{tabular}

Phyto, phytosterol.

* The large standard deviations for some sterols are owing to a large effect of the different diets; see Fig. 3.

phytosterols present in the feed (stigmasta-dienol, stigmast-enol and d-7-avenasterol) was not calculated, owing to levels in whole fish $<1 \mathrm{mg} / \mathrm{kg}$ fish for many of the samples, which were not considered to give reliable retention calculations. Retention of sum phytosterols correlated only to dietary phytosterols at $12^{\circ} \mathrm{C}\left(R^{2} 0.37\right.$, $P=0.001)$, whereas at $6^{\circ} \mathrm{C}$ it correlated equally well to both dietary phytosterols and dietary cholesterol (both $R^{2} 0.40, P=0.005$ ). Retention values were mainly similar at the two temperatures, with the exception of brassicasterol, which had a 2-fold-higher retention at $12^{\circ} \mathrm{C}$ compared with $6^{\circ} \mathrm{C}$ (Fig. 3, Table 3). The phytosterol: cholesterol ratio did not explain more of the variation than phytosterols or cholesterol alone for any of the retention data.

\section{Tissue ratios}

The ratio of cholesterol content in the mid-intestine to cholesterol in the feed, which says something about intestinal absorption, was approximately 2.5 at both temperatures, whereas the ratios for the different phytosterols ranged from 0.03 to 0.22 (Fig. 4). There were also significant differences between the individual phytosterols at both temperatures, with the highest ratio for campesterol, followed by brassicasterol, whereas campestanol, stigmastanol, $\beta$-sitosterol and sitostanol were similarly low (Fig. 4). The ratio of sterol content in bile to sterol content in liver, which says something about biliary excretion, was much higher for campesterol, $\beta$-sitosterol and sitostanol, compared with the other sterols (Fig. 5). Regarding the ratio between sterol content in adipose tissue to liver, which says something about the extent to which sterols are transported to and stored in this tissue, the ratio was highest for brassicasterol at both temperatures, but more so at $12^{\circ} \mathrm{C}$, whereas stigmasterol had a higher ratio at $12^{\circ} \mathrm{C}$ but not at $6^{\circ} \mathrm{C}$ (Fig. 5).

\section{Gene expression in intestine}

There were no significant differences in the RNA transcription of $A C A T 2, N C P 1 L 1, A B C G 5$ or $A B C A 1$ between the diet groups $0 / 0,0 / 1000,2000 / 0$ and 2000/2000 at either temperature (data not shown).

\section{Discussion}

Phytosterols have been sparsely studied in fish, but are now increasing in aquafeeds, whereas cholesterol is decreasing, owing to increased replacement of fishmeal and fish oil with plant-based feed ingredients and especially with the use of rapeseed oil. Changes in sterol levels can have marked effects on membrane properties, affecting signal transduction and
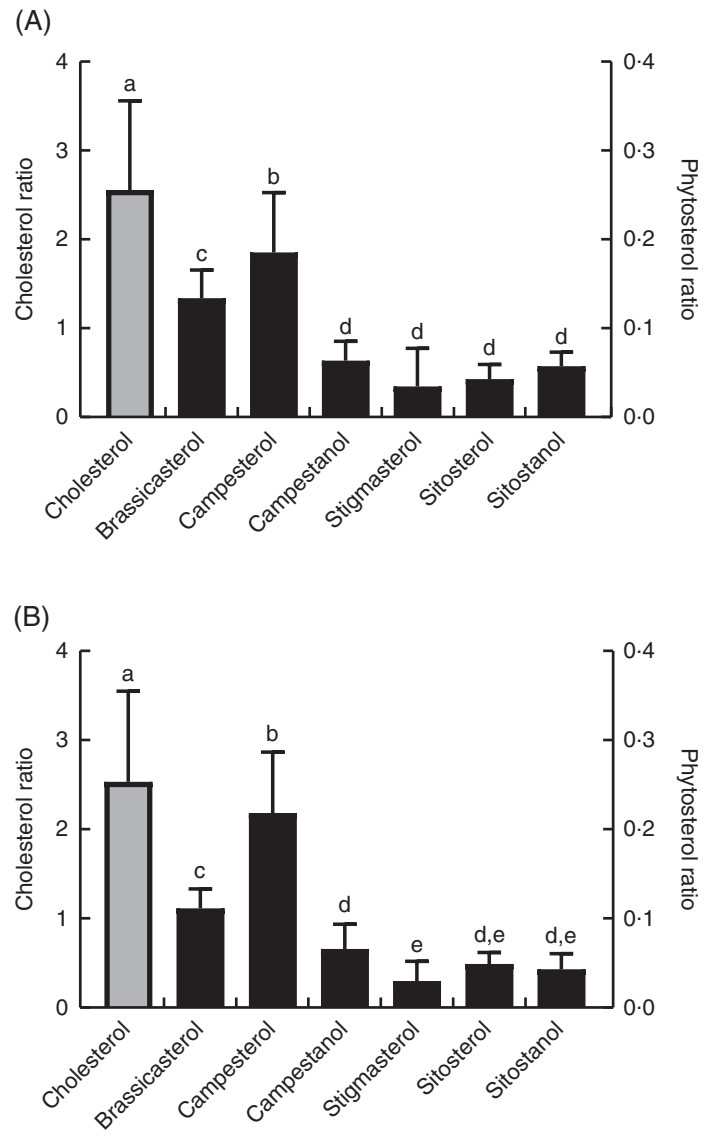

Fig. 4. The ratio of individual sterol content in the mid-intestine to the content in the feed at $12^{\circ} \mathrm{C}(\mathrm{A})$ and $6^{\circ} \mathrm{C}(\mathrm{B})$, which can give an indication about differences in absorption between the different sterols (although cholesterol will also be present as part of the cell membranes). Please note the 10-fold difference in scale of the cholesterol data (left-hand scale, $\square$ ) compared with the phytosterol data (right-hand scale, $\square$ ). All diet groups are combined. ${ }^{\mathrm{a}-\mathrm{e}}$ Values with unlike letters were significantly different $(P<0.05)$.

trafficking of membrane proteins and lipids ${ }^{(28)}$. Cholesterol also plays an important role in thermal adaptation of ectotherm animals, as incorporation of cholesterol into biological membranes affects membrane order and fluidity, stabilising membranes at high temperatures ${ }^{(19)}$. Hence, knowledge is needed regarding phytosterol absorption, possible interference with cholesterol absorption and tissue cholesterol levels, excretion and tissue distribution of dietary phytosterols in the major aquaculture species Atlantic salmon. The phytosterol and cholesterol levels used in the present study cover the range found in commercial Norwegian salmon diets ${ }^{(29)}$. 
(A)

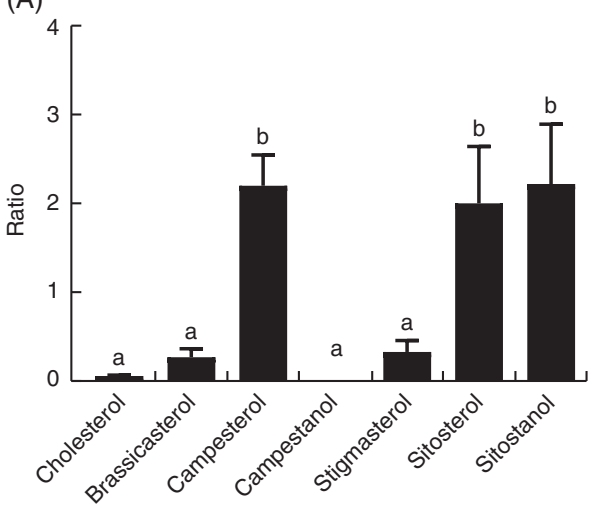

(C)

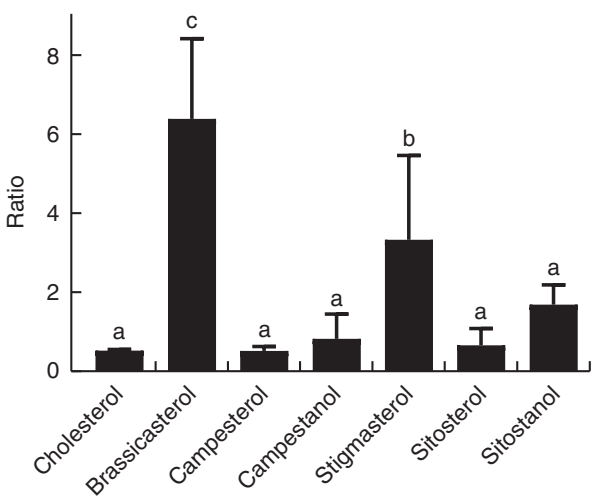

(B)

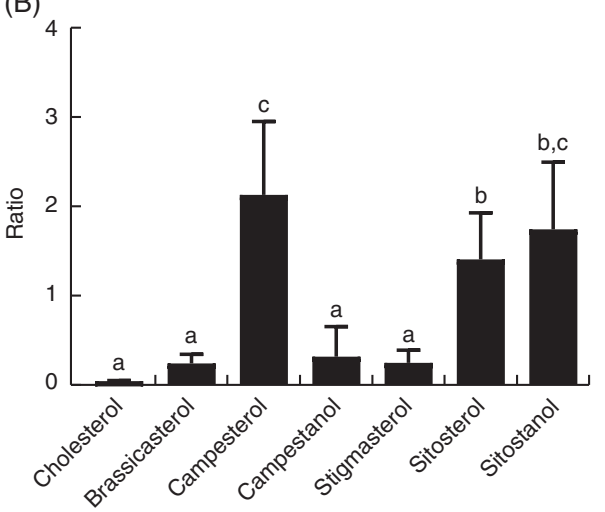

(D)

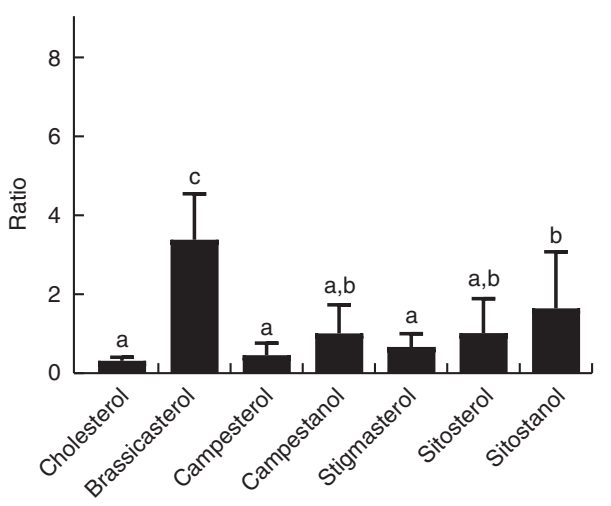

Fig. 5. The ratio of individual sterols in the bile $(A, B)$ and adipose tissue $(C, D)$ to the content in the liver, which can give an indication about differences in excretion through the bile and deposition in adipose tissue between the different sterols. All diet groups are combined. ${ }^{\text {a,b,c }}$ Values with unlike letters were significantly different $(P<0.05)$.

The intestinal absorption is the first place where discrimination between cholesterol and phytosterols, and between the individual phytosterols, occurs. The differences in the phytosterol: cholesterol ratios between the mid-intestine and the feed in the present trial indicate a higher absorption of cholesterol compared with phytosterols, as well as of campesterol, and, second, brassicasterol compared with the other phytosterols. Important factors for sterol absorption are solubilisation in micelles, and then transfer rate from the micelles, which combined correlated well with lymphatic recovery of sterols in rats ${ }^{(30)}$. While Hamada et $a l^{(30)}$ found the highest absorption for cholesterol, followed by campesterol and then similarly low values for brassicasterol and $\beta$-sitosterol, others have reported a higher absorption of brassicasterol both in rats and humans ${ }^{(31,32)}$, which is more in line with our results. Higher proportional brassicasterol in the intestine at $12^{\circ} \mathrm{C}$ may indicate a higher absorption of this sterol at this temperature, possibly explaining the higher retention also seen at this temperature. In 2004 it was shown both in rats, mice and humans that NCP1L1 is critical for intestinal cholesterol absorption $^{(33)}$, but this has not yet been confirmed in teleosts. To enter the bloodstream from the enterocyte, sterols can either be esterified by ACAT2 and incorporated into chylomicrons or be directly loaded onto apoA/HDL particles by ABCA1. Unesterified sterols present in the enterocyte are excreted back into the intestinal lumen by the heterodimeric transport proteins ABCG5/G8. NCP1L1, ACAT1 and ABCG5/G8 in the intestine do not discriminate between cholesterol and phytosterols, but ACAT2 displays cholesterol preference ${ }^{(34)}$. Excretion by ABCG5/G8 happens quite rapidly after absorption ${ }^{(35)}$; hence, this had probably to a large extent already occurred at the time point we sampled in the present trial ( $24 \mathrm{~h}$ after feeding). The clear differences in apparent absorption between the different sterols also support this; if less differences had been found, one could have suspected that the sampling had taken place midabsorption. Cholesterol absorption does not seem to be affected by dietary phytosterols in the present trial, which might relate to the levels of phytosterols present, which were chosen to be relevant for aquaculture feeds. In a previous trial with Atlantic salmon smolt, dietary phytosterols from rapeseed oil in the feed did not significantly affect apparent digestibility of cholesterol ${ }^{(5)}$. Gene expression of the intestinal transporters ( $A B C G 5$ and NPC1L1) was not significantly affected in our trial, whereas results on this in other animal models have varied ${ }^{(12)}$. NPC1L1 expression in $\mathrm{CaCo} 2$ cells was affected by PUFA but not by phytosterols ${ }^{(36)}$, and DHA added to Caco-2 cells or fish oil in the diet of hamsters reduced intestinal expression of $N C P 1 L 1^{(37)}$. This might explain expression differences in other salmon feeding trials where differences both in dietary sterols and dietary fatty acid composition occurred simultaneously ${ }^{(6)}$, but not in the present experiment.

Another important factor affecting the retention/deposition of sterols in the fish is biliary excretion, and the bile:liver ratios of 
the individual sterols can indicate whether certain sterols are preferentially excreted. Our results show that campesterol, $\beta$-sitosterol and sitostanol are excreted in bile to a large extent. Very low content of brassicasterol in the bile, combined with relatively high apparent absorption, helps explain why this phytosterol accumulates in the adipose tissue in the present trial. In humans, higher biliary secretion of $\beta$-sitosterol compared with campesterol has been reported ${ }^{(38,39)}$, which does not seem to be the case for Atlantic salmon. The very low biliary excretion of brassicasterol in Atlantic salmon also points to possible species differences, as in wild-type mice the bile:liver ratios of individual phytosterols were similarly high for brassicasterol and $\beta$-sitosterol, whereas lower for campesterol ${ }^{(40)}$. However, consistent with our results, another study in Atlantic salmon reported an apparent digestibility of campesterol of $14-18 \%$, 9\% for brassicasterol and $1-7 \%$ for $\beta$-sitosterol ${ }^{(5)}$. The general rank of efficiency of biliary sterol secretion in animals has been reported as cholesterol $>$ campesterol $>$ brassicasterol $>\beta$-sitosterol $>$ stigmasterol $^{(41)}$, which is in line with our data, with the exception of brassicasterol. ABCG5/G8-mediated secretion of non-cholesterol sterols into bile plays a crucial role in preventing their accumulation in liver, and minor structural differences in the sterols seem to have a profound effect on trafficking by ABCG5/G8 in the liver, but it is unclear why ${ }^{(41)}$. However, there is also ABCG5/G8-independent secretion of sterols into bile, at least in mice ${ }^{(40)}$; hence, species differences may relate to the relative importance of the different pathways in the different species. Brassicasterol, for which excretion and deposition in salmon seemed to deviate most from mammals, is abundant in rapeseed oil, but also in the marine food chain, both in certain microalgae and in mollusks ${ }^{(42,43)}$, which could mean that wild salmon is also exposed to this phytosterol.

Unlike cholesterol in other tissues, which is mainly incorporated into membranes in the form of free cholesterol, the liver also stores a substantial amount of its cholesterol as cholesteryl ester in the sterol ester pool ${ }^{(44)}$. Changes in hepatic cholesterol levels can thus be due to changes in this rapidly exchangeable pool of sterol esters to be transported to the plasma. The slower rate of this transport at the lower temperatures may therefore be the cause of the higher liver cholesterol at $6^{\circ} \mathrm{C}$. This is supported by also plasma levels being higher at $6^{\circ} \mathrm{C}$, whereas whole-body levels were similar. Slower metabolism at $6^{\circ} \mathrm{C}$ may also explain the results for the phytosterols, which were higher both in liver and bile at $6^{\circ} \mathrm{C}$, whereas whole fish levels and retention values were similar, suggesting a similar total biliary excretion at the two temperatures. The high TAG content in the liver of the fish reared at $6^{\circ} \mathrm{C}$ compared with $12^{\circ} \mathrm{C}^{(21)}$ may also be a factor in the increased liver sterol content at this temperature. The increasing liver cholesterol with dietary cholesterol found at $12^{\circ} \mathrm{C}$, but not at $6^{\circ} \mathrm{C}$ (possibly due to the high variation at this temperature), is previously reported in Atlantic salmon ${ }^{(6)}$. Liland et al. ${ }^{(6)}$ reported phytosterol levels in liver of Atlantic salmon at up to 117 and $155 \mathrm{mg} / \mathrm{kg}$ in two different feeding trials, which is higher than in the present trial, especially at $12^{\circ} \mathrm{C}$. In those two trials, fish were reared at 9 and $10^{\circ} \mathrm{C}$, and had lower maximum dietary phytosterol levels than in the present trial, but the fish were bigger (approximately $3 \mathrm{~kg}$ ) and were fed the experimental diets for a longer period, which might explain the difference to our trial.
Generally, tissue cholesterol correlated more pronounced to dietary cholesterol, whereas tissue campesterol correlated more strongly to the dietary phytosterol:cholesterol ratio. For campesterol retention, increasing dietary cholesterol had a negative effect, possibly indicating lower intestinal absorption when there is increasing 'competition' from cholesterol. On the other hand, retention of brassicasterol was more dependent on the dietary concentration of phytosterols, and the decreasing retention with increasing dietary level explains why tissue levels of brassicasterol remained unaffected by dietary phytosterols. The fact that retention of campesterol was affected by dietary cholesterol, while the retention of brassicasterol was most affected by dietary phytosterol, indicated differences in the absorption of these two phytosterols. Hamada et $a l .{ }^{(30)}$ showed that campesterol was much more solubilised in the micelles than brassicasterol, whereas this was to some extent compensated by the higher transfer rate of brassicasterol from the micelles. The clear temperature difference in brassicasterol retention and tissue levels has to our knowledge not been reported before, and interestingly did not apply to any of the other phytosterols, once again indicating differences in the absorption and/or excretion mechanisms. Cholesterol uptake was shown to be temperature dependent in an in vitro human intestine model $^{(18)}$, but this has to our knowledge not been investigated for the different phytosterols. Although retention of cholesterol was higher at $6^{\circ} \mathrm{C}$, the fact that whole-body concentration was similar shows that this might be more related to differences in feed intake and feed conversion at the two temperatures. The retention results for cholesterol prove a high extent of de novo production in Atlantic salmon when fed low dietary levels, although fish fed low dietary cholesterol did not fully compensate, as tissue cholesterol levels generally correlated positively with dietary cholesterol. On the contrary, in a feeding study with rainbow trout, there was significantly more cholesterol in whole body of the fish fed the vegetable oil diet without cholesterol fortification compared with if extra cholesterol was added to the diet ${ }^{(45)}$, indicating an overcompensation in the endogenous cholesterol production when dietary levels were low. Dietary rapeseed oil compared with fish oil affected plasma lipoproteins ${ }^{(46)}$ and reduced the total plasma cholesterol and LDLcholesterol in Atlantic salmon ${ }^{(47)}$. In light of the present results, this was probably more related to the decreased dietary cholesterol rather than the increased phytosterols.

One dinner portion ( $150 \mathrm{~g}$ ) of fillet with the highest phytosterol content from our trial would just contain $4.2 \mathrm{mg}$ of phytosterols. In comparison, one tablespoon $(8 \mathrm{~g})$ of a highphytosterol oil as maize oil (up to $15.6 \mathrm{mg}$ phytosterols/g oil ${ }^{(47)}$ ) provides $125 \mathrm{mg}$ of phytosterols. The content of phytosterols in a typical Western diet varies between 160 and $360 \mathrm{mg} / \mathrm{d}$, being even higher for vegetarians ${ }^{(49-51)}$. Although a larger fish with a higher fillet lipid content (the normal harvest size of Atlantic salmon is approximately $5 \mathrm{~kg}$ ) might accumulate somewhat higher phytosterol levels than the $900 \mathrm{~g}$ fish in our study, farmed salmon fed rapeseed oil will only make a very minor contribution to phytosterol intake in humans.

In conclusion, dietary phytosterols did not seem to affect cholesterol absorption or tissue cholesterol levels, and, furthermore, did not affect tissue phytosterol levels, as this was more affected by dietary cholesterol and the phytosterol: 
cholesterol ratio. Campesterol and, second, brassicasterol appear to be the phytosterols with the highest intestinal absorption in Atlantic salmon, and are also the ones that accumulate to the highest extent in tissues. Unlike campesterol, there was hardly any biliary excretion of brassicasterol, resulting in even higher retention of brassicasterol than campesterol. Brassicasterol appears to particularly accumulate in adipose tissue, and interestingly also has a 2-fold-higher retention at $12^{\circ} \mathrm{C}$ compared with $6^{\circ} \mathrm{C}$. This study clearly shows that there are differences in how the individual phytosterols are absorbed, excreted and deposited in tissues of Atlantic salmon.

\section{Acknowledgements}

The authors thank Synnøve Winterthun, Ikram Belghit and Nathaniel Sibinga from NIFES for valuable help with the samplings.

The study was kindly funded by The Norwegian Seafood Research Fund - FHF (grant number: 901049, 'Steroltemp'). Bashir Adbulkader, Joar Breivik, Eva Mykkeltvedt and Hui-Shan Tung at NIFES are acknowledged for technical assistance with sample analyses, and Tårn Helgøy Thomsen from Skretting ARC is acknowledged for technical assistance at the Lerang research station.

N. S. L., N. H. S. and G. R. designed and planned the trial; I. S. formulated the diets; N. S. L., N. H. S. and G. R. participated in sampling; N. S. L. was responsible for gene expression analyses and data; and N. H. S. was responsible for sterol analyses and data. N. H. S. was the main author of the manuscript, but all authors participated in the writing of the manuscript and approved the final version.

There are no conflicts of interest.

\section{Supplementary materials}

For supplementary material/s referred to in this article, please visit https://doi.org/10.1017/S0007114517003853

\section{References}

1. Piironen V, Lindsay DG, Miettinen TA, et al. (2000) Plant sterols: biosynthesis, biological function and their importance to human nutrition. J Sci Food Agric 80, 939-966.

2. Gilman CI, Leusch FDL, Carl Breckenridge W, et al. (2003) Effects of a phytosterol mixture on male fish plasma lipoprotein fractions and testis $\mathrm{P} 450 \mathrm{scc}$ activity. Gen Comp Endocrinol 130, 172-184.

3. Gordon MH \& Miller LAD (1997) Development of steryl ester analysis for the detection of admixtures of vegetable oils. $J \mathrm{Am}$ Oil Chem Soc 74, 505-510.

4. Ytrestøyl T, Aas TS \& Åsgård T (2015) Utilisation of feed resources in production of Atlantic salmon (Salmo salar) in Norway. Aquaculture 448, 365-374

5. Miller M, Nichols P \& Carter C (2008) The digestibility and accumulation of dietary phytosterols in Atlantic Salmon (Salmo salar L.) smolt fed diets with replacement plant oils. Lipids 43, 549-557.

6. Liland NS, Espe M, Rosenlund G, et al. (2013) ) High levels of dietary phytosterols affect lipid metabolism and increase liver and plasma TAG in Atlantic salmon (Salmo salar L.). Br J Nutr 110, 1958-1967.
7. Katan MB, Grundy SM, Jones P, et al. (2003) Efficacy and safety of plant stanols and sterols in the management of blood cholesterol levels. Mayo Clin Proc 78, 965-978.

8. Patel MD \& Thompson PD (2006) Phytosterols and vascular disease. Atherosclerosis 186, 12-19.

9. Ling WH \& Jones PJH (1995) Dietary phytosterols: a review of metabolism, benefits and side effects. Life Sci 57, 195-206.

10. Field FJ, Born E \& Mathur SN (1997) Effect of micellar beta-sitosterol on cholesterol metabolism in $\mathrm{CaCo}-2$ cells. J Lipid Res 38, 348-360.

11. Mel'nikov SM, Seijen ten Hoorn JWM \& Eijkelenboom APAM (2004) Effect of phytosterols and phytostanols on the solubilization of cholesterol by dietary mixed micelles: an in vitro study. Chem Phys Lipids 127, 121-141.

12. Calpe-Berdiel L, Escolà-Gil JC \& Blanco-Vaca F (2009) New insights into the molecular actions of plant sterols and stanols in cholesterol metabolism. Atherosclerosis 203, 18-31.

13. Ostlund RE \& Lin X (2006) Regulation of cholesterol absorption by phytosterols. Curr Atheroscler Rep 8, 487-491.

14. Sanders DJ, Minter HJ, Howes D, et al. (2000) The safety evaluation of phytosterol esters. Part 6. The comparative absorption and tissue distribution of phytosterols in the rat. Food Chem Toxicol 38, 485-491.

15. Sabeva NS, McPhaul CM, Li X, et al. (2011) Phytosterols differentially influence $\mathrm{ABC}$ transporter expression, cholesterol efflux and inflammatory cytokine secretion in macrophage foam cells. J Nutr Biochem 22, 777-783.

16. Bendiksen EÅ, Berg OK, Jobling M, et al. (2003) Digestibility, growth and nutrient utilisation of Atlantic salmon parr (Salmo salar L.) in relation to temperature, feed fat content and oil source. Aquaculture 224, 283-299.

17. Ruyter B, Moya-Falcòn C, Rosenlund G, et al. (2006) Fat content and morphology of liver and intestine of Atlantic salmon (Salmo salar): Effects of temperature and dietary soybean oil. Aquaculture 252, 441-452.

18. Sviridov DD, Safonova IG, Nano JL, et al. (1993) New model to study cholesterol uptake in the human intestine in vitro. I Lipid Res 34, 331-339.

19. Crockett EL (1998) Cholesterol function in plasma membranes from ectotherms: membrane-specific roles in adaptation to temperature. Am Zool 38, 291-304.

20. Sissener NH, Liland NS, Holen E, et al. (2017) Phytosterols are not involved in the development of fatty liver in plant oil fed Atlantic salmon (Salmo salar) at high or low water temperature. Aquaculture 480, 123-124.

21. Laakso P (2005) Analysis of sterols from various food matrices. Eur J Lipid Sci Technol 107, 402-410.

22. Sissener NH, Hemre GI, Lall SP, et al. (2011) Are apparent negative effects of feeding genetically modified (GM) MON810 maize to Atlantic salmon, Salmo salar L caused by confounding factors? Br J Nutr 106, 42-56.

23. Higuchi R, Fockler C, Dollinger G, et al. (1993) Kinetic PCR analysis: real-time monitoring of DNA amplification reactions. Nat Biotech 11, 1026-1030.

24. Vandesompele J, De Preter K, Pattyn F, et al. (2002) Accurate normalization of real-time quantitative RT-PCR data by geometric averaging of multiple internal control genes. Genome Biol 3, RESEARCH0034.

25. R Development Core Team (2011) R: A language and environment for statistical computing. Vienna, Austria: R Foundation for Statistical Computing.

26. Pinheiro J, Bates D, DebRoy S, et al. (2017) nlme: Linear and Nonlinear Mixed Effects Models. R package version 3.1-131. https://CRAN.R-project.org/package=nlme.

27. Hothorn T, Bretz F \& Westfall P (2008) Simultaneous inference in general parametric models. Biom J 50, 346-363. 
28. Maxfield FR \& Menon AK (2006) Intracellular sterol transport and distribution. Curr Opinion Cell Biol 18, 379-385.

29. Sanden M, Hemre G, Måge A, et al. (2017) Program for overvåking av fiskefôr. Årsrapport for prøver innsamlet i 2016 (Program for surveillance of fish feed. Annual report for samples collected in 2016). Bergen: NIFES.

30. Hamada T, Goto H, Yamahira T, et al. (2006) Solubility in and affinity for the bile salt micelle of plant sterols are important determinants of their intestinal absorption in rats. Lipids $\mathbf{4 1}$ 551-556.

31. Vahouny GV, Connor WE, Roy T, et al. (1981) Lymphatic absorption of shellfish sterols and their effects on cholesterol absorption. Am J Clin Nutr 34, 507-513.

32. Gregg RE, Connor WE, Lin DS, et al. (1986) Abnormal metabolism of shellfish sterols in a patient with sitosterolemia and xanthomatosis. J Clin Invest 77, 1864-1872.

33. Altmann SW, Davis HR, Zhu L-j, et al. (2004) Niemann-Pick C1 like 1 protein is critical for intestinal cholesterol absorption. Science 303, 1201-1204.

34. Brauner R, Johannes C, Ploessl F, et al. (2012) Phytosterols reduce cholesterol absorption by inhibition of 27hydroxycholesterol generation, liver $\mathrm{X}$ receptor $\alpha$ activation, and expression of the basolateral sterol exporter ATP-binding cassette A1 in Caco-2 enterocytes. J Nutr 142, 981-989.

35. Igel M, Giesa U, Lütjohann D, et al. (2003) Comparison of the intestinal uptake of cholesterol, plant sterols, and stanols in mice. J Lipid Res 44, 533-538.

36. Park Y \& Carr TP (2013) Unsaturated fatty acids and phytosterols regulate cholesterol transporter genes in Caco-2 and HepG2 cell lines. Nutr Res 33, 154-161.

37. Mathur SN, Watt KR \& Field FJ (2007) Regulation of intestinal NPC1L1 expression by dietary fish oil and docosahexaenoic acid. J Lipid Res 48, 395-404.

38. Sudhop T, Sahin Y, Lindenthal B, et al. (2002) Comparison of the hepatic clearances of campesterol, sitosterol, and cholesterol in healthy subjects suggests that efflux transporters controlling intestinal sterol absorption also regulate biliary secretion. Gut 51, 860-863.

39. Brufau G, Canela MA \& Rafecas M (2008) Phytosterols: physiologic and metabolic aspects related to cholesterol-lowering properties. Nutr Res 28, 217-225.
40. Dikkers A, Freak de Boer J, Annema W, et al. (2013) Scavenger receptor BI and ABCG5/G8 differentially impact biliary sterol secretion and reverse cholesterol transport in mice. Hepatology 58, 293-303.

41. Yu L, von Bergmann K, Lutjohann D, et al. (2004) Selective sterol accumulation in ABCG5/ABCG8-deficient mice. J Lipid Res 45, 301-307.

42. Gladu PK, Patterson GW, Wikfors GH, et al. (1990) The occurrence of brassicasterol and epibrassicasterol in the chromophycota. Comp Biochem Physiol B Comp Biochem 97, 491-494.

43. Sinclair AJ, Murphy KJ \& Li D (2000) Marine lipids: overview "news insights and lipid composition of Lyprinol". Allerg Immunol 32, 261-271.

44. Alhazzaa R, Oen JJJ \& Sinclair AJ (2013) Dietary phytosterols modify the sterols and fatty acid profile in a tissue-specific pattern. J Funct Foods 5, 829-837.

45. Norambuena F, Lewis M, Hamid NKA, et al. (2013) Fish oil replacement in current aquaculture feed: is cholesterol a hidden treasure for fish nutrition? PLOS ONE $\mathbf{8}$, e81705.

46. Torstensen BE, Frøyland L \& Lie $\varnothing$ (2004) Replacing dietary fish oil with increasing levels of rapeseed oil and olive oil - effects on Atlantic salmon (Salmo salar L.) tissue and lipoprotein lipid composition and lipogenic enzyme activities. Aquac Nutr 10, 175-192.

47. Jordal A-EO, Lie $\varnothing$ \& Torstensen BE (2007) Complete replacement of dietary fish oil with a vegetable oil blend affect liver lipid and plasma lipoprotein levels in Atlantic salmon (Salmo salar L.). Aqua Nutr 13, 114-130.

48. Piironen V, Toivo J \& Lampi AM (2000) Natural sources of dietary plant sterols. J Food Comp Anal 13, 619-624.

49. Connor W (1968) Dietary sterols: their relationship to atherosclerosis. J Am Diet Assoc 52, 202-208.

50. Cerqueira MT, Fry MM \& Connor WE (1979) The food and nutrient intakes of the Tarahumara Indians of Mexico. Am J Clin Nutr 32, 905-915.

51. de Vries JHM, Jansen A, Kromhout D, et al. (1997) The fatty acid and sterol content of food composites of middle-aged men in seven countries. J Food Comp Anal 10, 115-141. 